\title{
低コストマイクロコンピュータによる 教育システムと教材作成作業効果
}

Education system used Low-cost Micro-Computer and Draw up operation effects of Teaching material

$\begin{array}{llll}\text { 苅屋公 明 } * & \text { 高山 } & \text { 茂 } ※ \\ \text { Komyo KARIYA } & & \text { Shigeru TAKAYAMA }\end{array}$
ワーキングメンバー：林 実，谷村敬造，平山広宣※**

This study has been continued since 1983 。In the last report, an education method using Low-cost micro-computer was reported。 This report lays emphasis on the necessity of an unified computer aided education method and an intuitive and image learning method。And then it is suggested that Low-cost handy type computer be developed so that all students can carry it in their bags as well as their text books 。

This report deals with an education system using Low-cost micro computer and Draw up operations of teaching materials。 The problems of the harmony among computer aided education method and visual education method and effective operation method to construct education materials are particularly introduced。

本研究は1983年より継続されている。前回の報告（第33巻第 3 号）では低コ ストマイクロコンピュータを使用した一つの教育方法を報告した。この報告では ユニファイドしたコンピュータ利用教育と直観的および描写的 (イメージ的 ) 教 育方法の必要性を強調した。そしてすべての学生が教科書と同様にバッグに入れ て持つことのできる低コストコンピュータの開発を提案した。

今回は低コストマイクロコンピュータを用いた教育システムと教材の作成作業 を報告する。とくにコンピュータ利用教育と視聴覚教育との調和問題および教材 の効果的な作成方法を紹介する。

立命館大学理工学部電気工学科教授

Department of Electricity,

Faculty of Science and Engineering,

Ritsumeikan University

※ 立命館大学大学院理工学研究科電気工学尃攻博士課程

Graduate Course of Department of Electri- city, Faculty of Science and Engineering, Ritsumeikan University

※※ 立命館大学理工学部茂屋研究室 60 年度大学院生およ ひ卒業研究生

昭和60年度工業教育研究講演会 ( 1985-12-7)にお いて発表 


\section{1.はしがき}

本誌第 33 巻第 3 号で, 個人持ハンディタイプマイ クロコンピュータ，すなわち教科書化コンピュータ を実現させることを前提条件として，MS X規格に よる低コストマイクロコンピュー夕程度の機能で実 現できる簡単なグラフィックスを用いて教育効果を 高める直観的教育方法の検討結果を報告した ${ }^{1 ） 。 ~}$

本報は，そこで示した教育方法を現時点で比較的 多く使われているビデオシステムを中心とする視聴 覚教育方法に組み込むための教員のグラフイックス 作成作業システム。および教室のトータルビジュア ルシステムについて報告し，教員の作る直観的・動 的グラフィックスのハードコピーを用いた講義教育 との調和のとれた教科書作成作業について紹介する。

前報の後, わずか 1 年の間にもマイクロコンピュ 一夕を利用する教育は，小学校から大学に至るまで, さらに専門学校や塾においても普及を見てきた。ま たコンピュータを利用する教科書, 参考書も多数出 回ってきた。その大方は中程度のマイクロコンピュ ータやパーソナルコンピュータを利用する学習対話 式ソフトウェアに基づくもので，今後のソフトウェ ア開発がコンピュータ利用教育 (CAI-Computer Assisted Instruction）の発展と普及の「カギ」 を握ることはほぼ確実と思われる。文部省も「情報 社会に対応する初等・中等教育の調査研究協力者会 議」を設けて, 生徒や学生に及ぼす心理的ストレス に対して慎重な配慮を示しながらも, コンピュータ 利用教育のモデル校の設置, 教具としての積極的利 用によるコンピュータアレルギーの解消, 未来の高 度情報社会に対処できる資質の養成など,一定の見 解を示している2）。さらに, 視聴覚機器もコンピュ 一タとの連動を含めて変りつつある現状である。

一方では文部省の見解にもあるように, 真の教育, 心を育てる教育からの逸脱が心配されている。この ような状況の中で，著者らの検討しているコンピュ タ利用教育は,

1. 低コストマイクロコンピュータを利用し，近い 将来に教科書と同様にコンピュータを考えること が可能になるので，学生 (生徒) に低コストで供 給ができ, 体の一部になり得る点,

2. 使いやすいM S X規格ベーシックを基本とする ので, 教員も学生も親しみやすく, コンピュータ アレルギーをおこさない点,
3. 教員が授業や講義の前に簡単なグラフィックス 機能を用いた直観的動画面を作りやすい点, およ び教育効果を見ながらその動画面を修正しやすい 点

などから長年培われてきた講義教育の中に，調和の とれた形で組み込むことができ, 真の教育, 心を育 てる教育が助長できるものと考えている。

\section{2. 低コストマイクロコンピュータによる教 員の直観的・動的グラフィックス作成作 業を含むトータルビジュアルシステム}

コンピュータの教育への適用には 3 つの方向があ る。すなわち,

1. コンピュータそのものの教育 ( C L : Computer Literacy )

2. 成績処理その他の事務処理 ( C M I : Computer Managed Instruction)

3. コンピュータ支援学習 ( C A I / C AL :

Computer Assisted Instruction/Learning ) である ${ }^{3)}$ ，4）。本報告に示す教育方法は3.に属する が。なるべくユニファイドできる方法を確立してゆ くことが望まれる。すなわちコンピュータの機種の 更新によって操作を勉強しなおしたり，ソフトウェ アを組み変えたり，また家庭学習に使う機種と学校 で使う機種が違ったりすることは普遍性に之しく。 学習以前の時間の労費となるからである。なお, 現 時点においては, コンピュータの発展のスピードか らある程度の更新はやむを得ないとしてもシステム 上での更新にとどめるべきであり，これらの点を十 分配慮したシステムを確立してゆくべきである。

図 1 は教員が直観的・動的グラフィックスを作成 し，教科書やプリントと共に敏速に 1 授業単位ごと や 1 学期ごとに学生に供給できるシステムであり, 学生のもつコンピュータ, 従来から使われている視 聴覚機器との関係も含むトータルビジュアルシステ ムである。このシステムは前報 ${ }^{1)}$ で報告した低コ ストマイクロコンピュータによる直観的教育方法の 理念に基づいて構成された。

ブロックAは教員が準備室を含めてワークデスク に持つシステムであり, フロッピィディスク化，八 ードコピー化, カセットテープ化, およびビデオテ ープ化が可能な低コストマイクロコンピュータシス テムを構成している。ここでは直観的・動的グラフ イックスの編集と保管, 教科書の作成作業とその学 
生への供給，動的グラフィックスの学生への供給。 視聴覚用ビデオフィルムの教員への供給が実行され る。

ブロックBは教室に設置する視聴覚設備の構成例 である。この形態は学校の予算や規模に応じてフレ キシブルに考えることができるが，教卓内に収納す るのが望ましく,ブロックDの教室モニタやビデオ プロジェクタを含めて学校教室設備となる。

ブロックCは学生が個人で持つハンディタイプマ イクロコンピュータ (教科書化コンピュータ)であ って。ブロックB中の教員用マイクロコンピュータ も同一のものである。

ここに示したシステムは多目的に利用できる点で 特徴があり。直観的・動的グラフィックス（教育入 ニュー) はビデオシステムを用いても，マイクロコ ンピュータシステムを用いても，また両者を併用し ても学生に提示することができる。これに加えてビ ューアを用いて補足資料の提示も可能である。また 将来は教員用のコンピュータと学生のコンピュータ との間を無線で交信できるように検討中である。さ らにプリンタとコピー装置とを連結すれば授業中に 新たに構成したグラフイックスを即学生に配布する ことも可能である。

\section{3. 直観的・動的グラフィックスを利用 した教材作成作業効果}

前報 ${ }^{1)}$ で直観的・動的グラフィックスを作成する 「仕様書」の例，その仕様書に基づく実現グラフィ ックスおよび基本一展開一応用グラフィックスから 成るグラフィックス構成法を示して「仕様書のはた す役割」について説明した。その役割は学生の直観 性に訴え得る重要事項とその動点を的確に与えるこ とである。

本研究では 3 回生までに学生が学んだ電気系12科 目の教育内容を教員の作った仕様書に基づいて 4 回 生の卒業研究生と大学院院生及び教員が協力してグ ラフィックスを構成する作業をおこなっているが, 4 回生の卒業研究生は学んだ内容を復習する立場に あり，それまでにあまり良く理解できなかった内容 を教員の作った仕様書を基に学生レベルで理解でき るように, 動点の選び方, 速度の与え方, 動点の運 動と同期する音声の加え方, カラーの与え方, キャ ラクタの選び方などを興味をもって修正しており， 教員レベルと学生レベルとの理解の行き違いが是正 され，学生の直観性にきわめて良く適合したグラフ ィックスが順次構成されていっている。

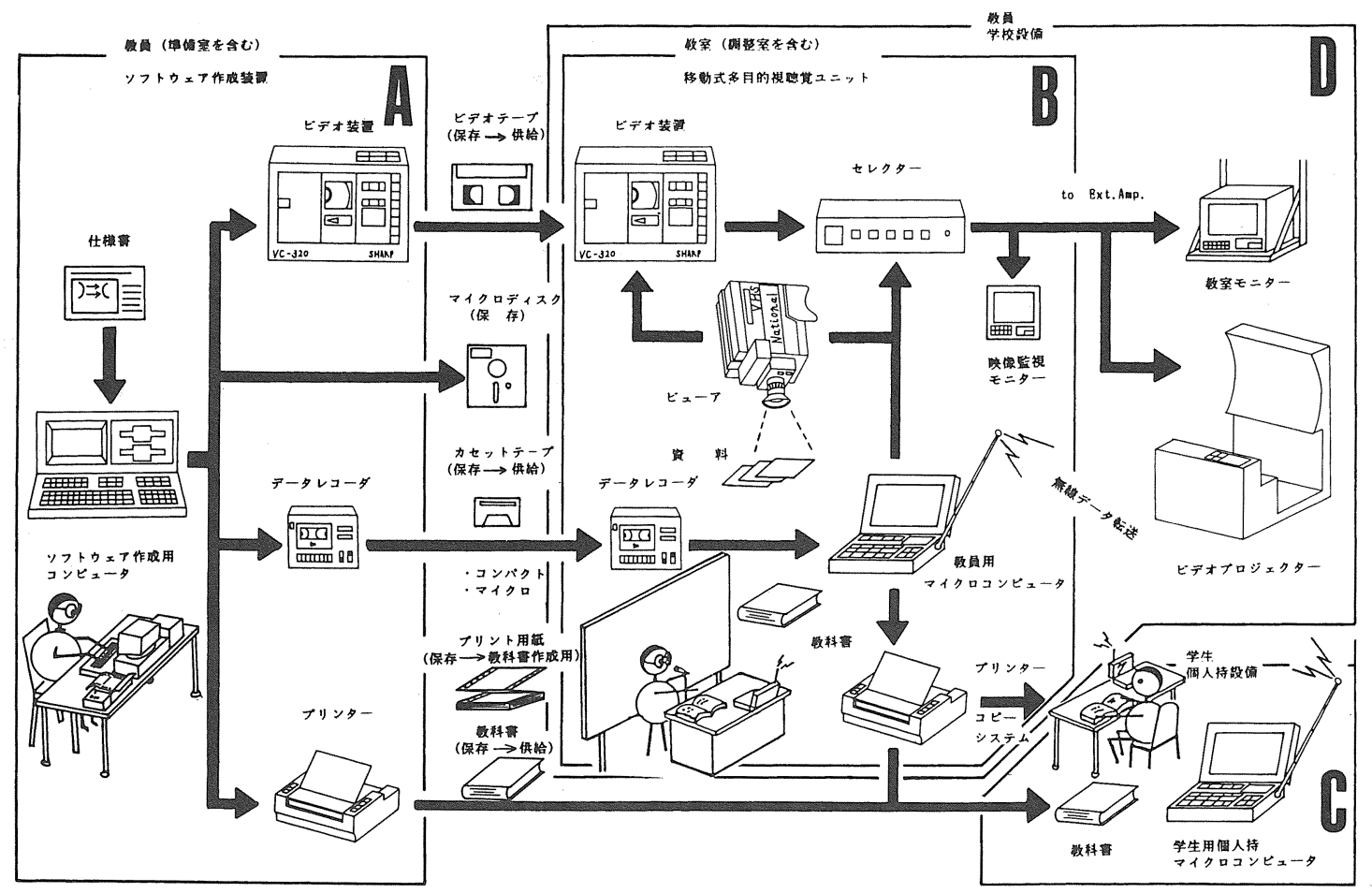

図1低コストマイクロコンピュータによる教育のシステム化 
一般に教科書は教員が教える立場で書かれるが, 本研究では学生が学ぶ立場で教材作成に参加するの で。実際の教育現場で下記の過程を経て作られた教 材（直観的・動的グラフィックス）を使ったとき。 学生に親しみやすく受け入れてもらえる理解度の高
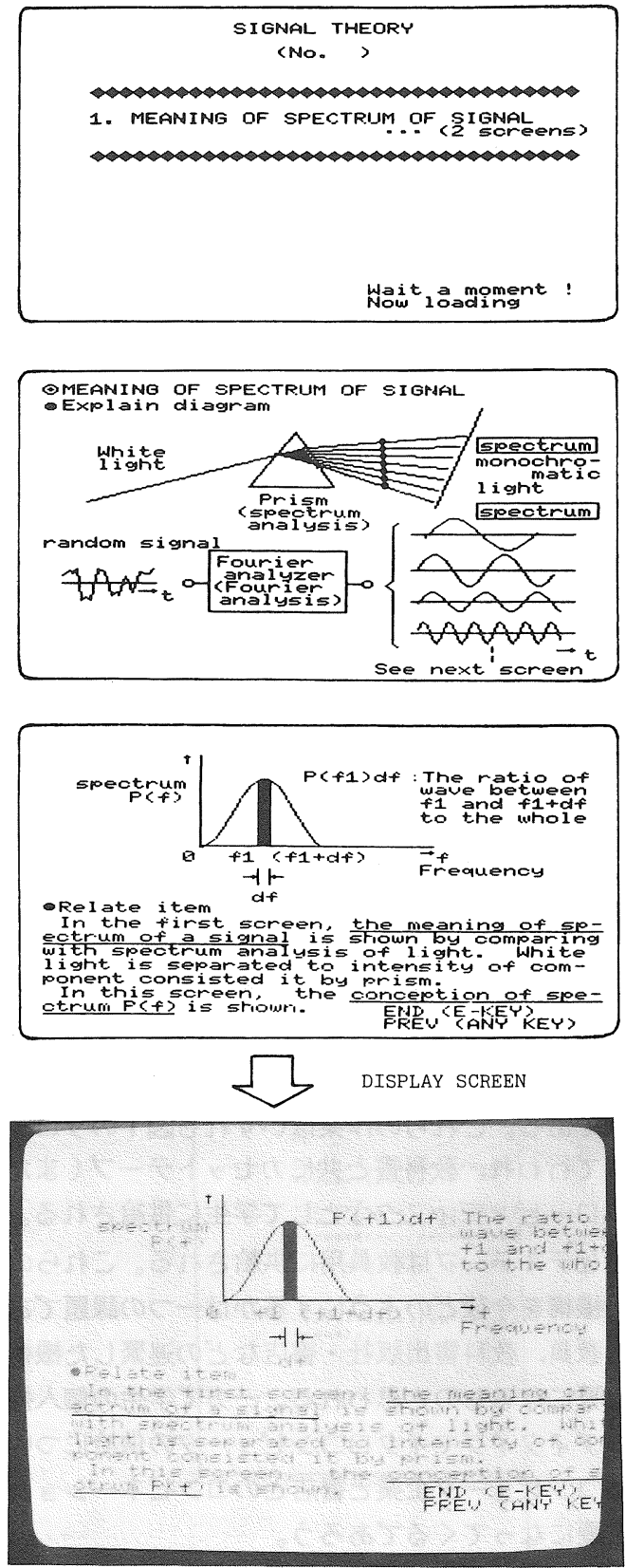

図 2 直観的・動的グラフィックスによる教材の 一つ作成例
い教材であるという評価を得ている。この評価は専 門科目の内容を動画面で与えることと学生自身が教 材作成に参加する点で非常に良い参考になると思わ れる。

図 2 は直観的・動的グラフィックスによる教材の 一つの作成例 ( 信号のスペクトルの意味を理解さす グラフィックスーハードコピーの結果とディスプレ イ画面一本来はカラ一画面一の写真 ) であるが。本 論文では動画面効果を示しにくい。そこで図 3 と図 4 に動画面の 1 コマ, 1 コマを順次追跡できるよう に配列した例を示しておく。

図 3 は著者らの大学のシンボルが 1 つの点を動か しながら順次構成されてゆく例であり，大学の校歌 を音声化して，校歌が終了すると同時にシンボルが 構成され終る。この動画面は学習の始めに学生の学 習意欲を喚起さすために使用している。
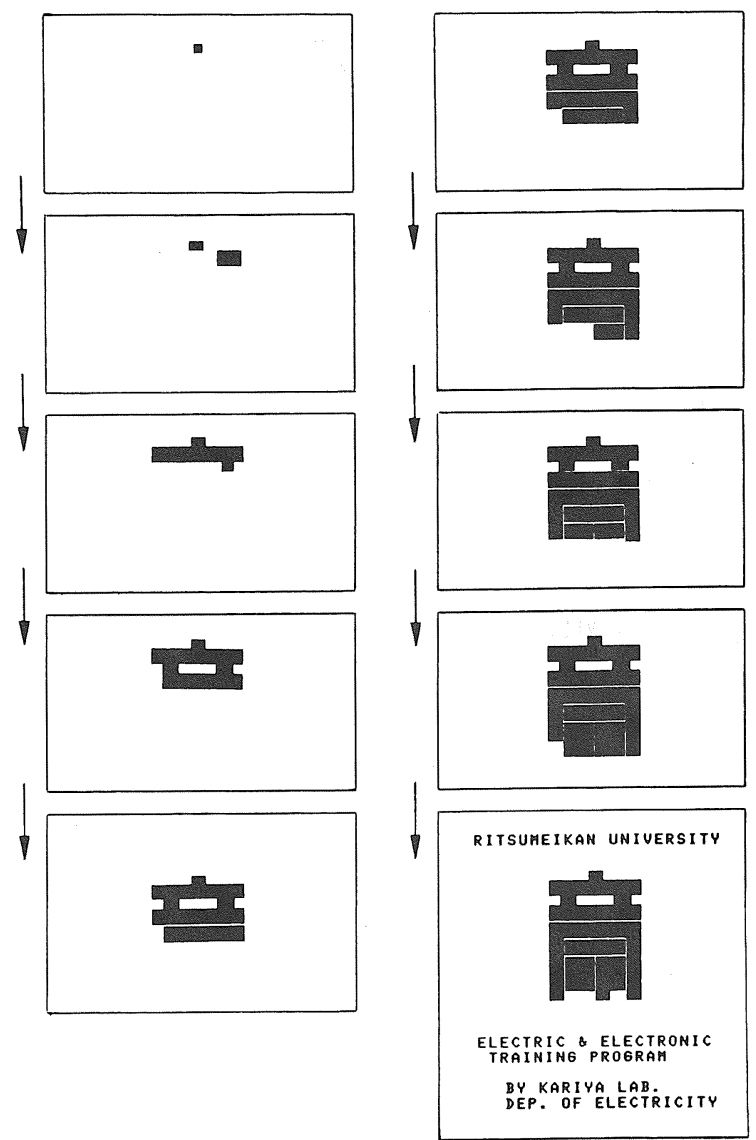

図 3 直観的・動的グラフィックスの動画面勃果 (その 1 ) 

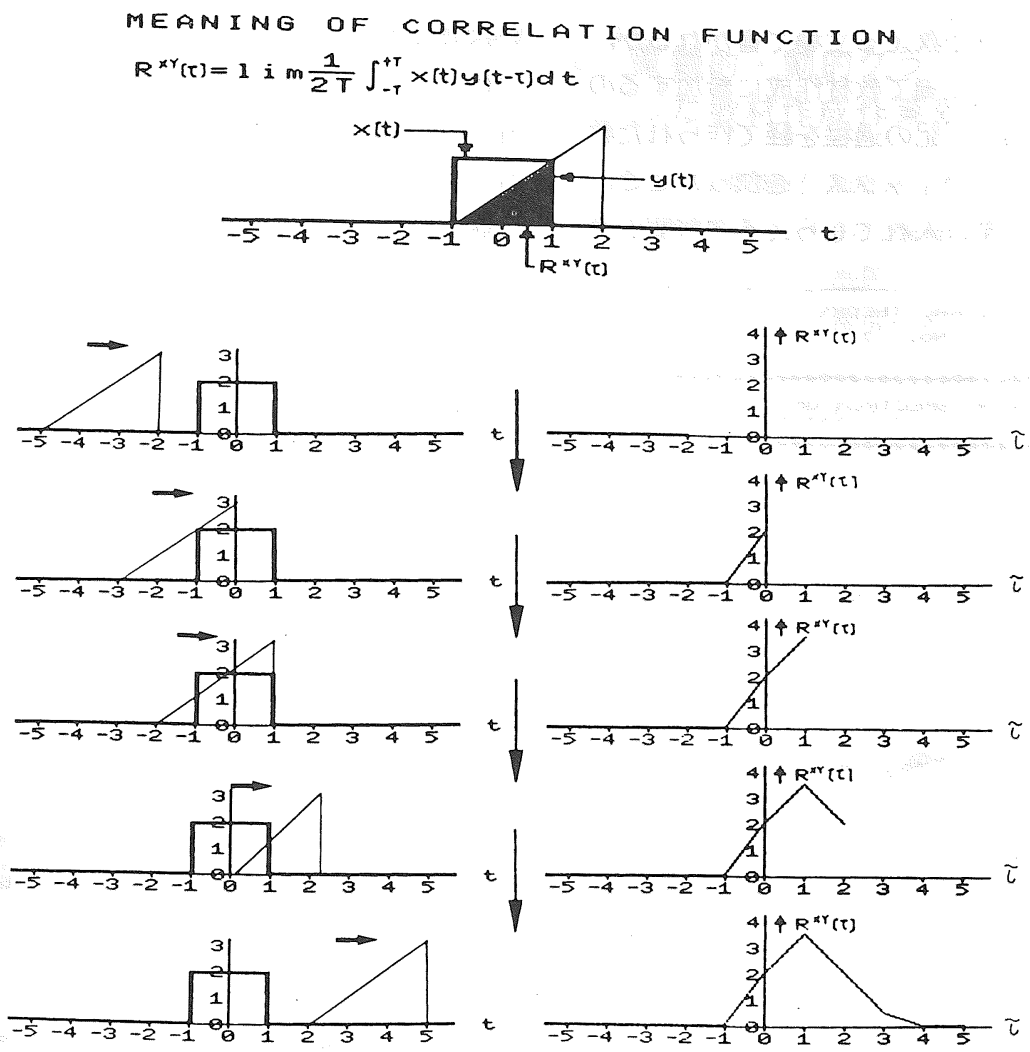

図4 直観的・動的グラフィックスの動画面勃果 (その 2 )

図 4 は学生がなかなか理解してくれない相関関数 の意味を効果的に理解させるための動的グラフィッ クスである。式

$$
R^{\mathrm{XY}}(\tau)=\lim \frac{1}{2 T} \int_{-T}^{T} x(t) y(t-\tau) d t
$$

は相互相関関数であるが，信号 $x(t)$ に短形波を， 信号 $y(t)$ に三角波を与えて, 短形波を固定してお き，三角波を左から右に動かしていき（式中のてを 動かす)，短形波と三角波が囲む面積值をグラフに プロットしていくと,相互相関関数 $R^{\mathrm{XY}}(\tau)$ となるこ とを示している。学生にこの動画面を提示すると相 互相関関数が一方の波形をずらしていくとき，ずら す時間ごとに変化する面積值の変化であることを直 ちに理解してくれるので, 教育効果が非常に高まる。

本教育システムの教材作成作業は大別して 4 つの 段階に分けられる。すなわち，

1. 直観的・動的グラフィックスの仕様書作成作業

2. 仕様書に基ずくグラフィックス (ソフトウェア) 作成作業, その結果のカセットテープ化(フロッ
ピィディスク化）とビデオテープ化作業

3. グラフィックスのハードコピー化作業

4. ハードコピーと調和のとれた教科書原稿 (プリ

ント)の作成作業, すなわち教科書化作業

である。このうち 1. . 4. は教員の作業でなければ ならないが，その他は少し訓練されたオペレータで 十分である。これらの作業はいずれも図 1 のブロッ クAで行われ, 教科書と共にカセットテープ（また はフロッピィディスク）として学生に供給される。 またビデオテープは教員用に供給される。これらの 供給機構を今後どのようにするかは一つの課題であ り, 教員, 教科書出版社・書店などの連緊した機構 が必要になるものと思われる。一方で学生の個人持 ハンディタイプマイクロコンピュータの供給につい てはコンピュータ企業と書店とのコンビネーション が必要になってくるであろう。

図 5 は動的グラフイックスのハードコピーを使用 した教科書原稿の作成例である。この作業は図 $1 の$ ブロックAのコンピュータのワードプロセッサ機能 
（またはワードプロセッサ専用機）を用いることと， 著者らが開発した低コストコンピュータ用ハードコ ピープログラムを用いることによって効率的に進め られる。

\section{4. むすび}

本報では前報 ${ }^{1)}$ と合わせて低コストマイクロコン ピュータを教科書化することを前提として, 動的グ ラフィックスによる直観的教育方法についての検討 結果を示した。コンピュータ利用教育の講義教育と の調和のとれた方法が実現できる見通しを得たが, 残る問題は学生のライフコストに見合う個人持ハン ディタイプマイクロコンピュータの提供問題である。 薄型カラーディスプレイの低コスト実現がそのキー ポイントになろうが, その実現への努力をおこない
ながら, さらに動的・直観的グラフィックスを増や していく考えである。

\section{参考文献}

1）刈屋公明：直観的教育方法と小型コンピュータ，工業 教育, 第 33 巻第 3 号 (1985)，pp. 18～25。

2）朝日新聞記事 : コンピュータの可能性，教育現場にど う生加す，1985年8月15日（朝刊）。

3）高橋賢：パーソナルコンピュータによる学習－CAL とLogo を中心に一，電気学会誌，第 105 巻第 10 号 (1985), pp. 959 962。

4) Komyo Kariya : Computerized Education and an Example on Measurement, IMEKO (International Measurement Confederation) TC-7 Symposium, 1986年6月( J ena-D D R ) 紹待講演論文。

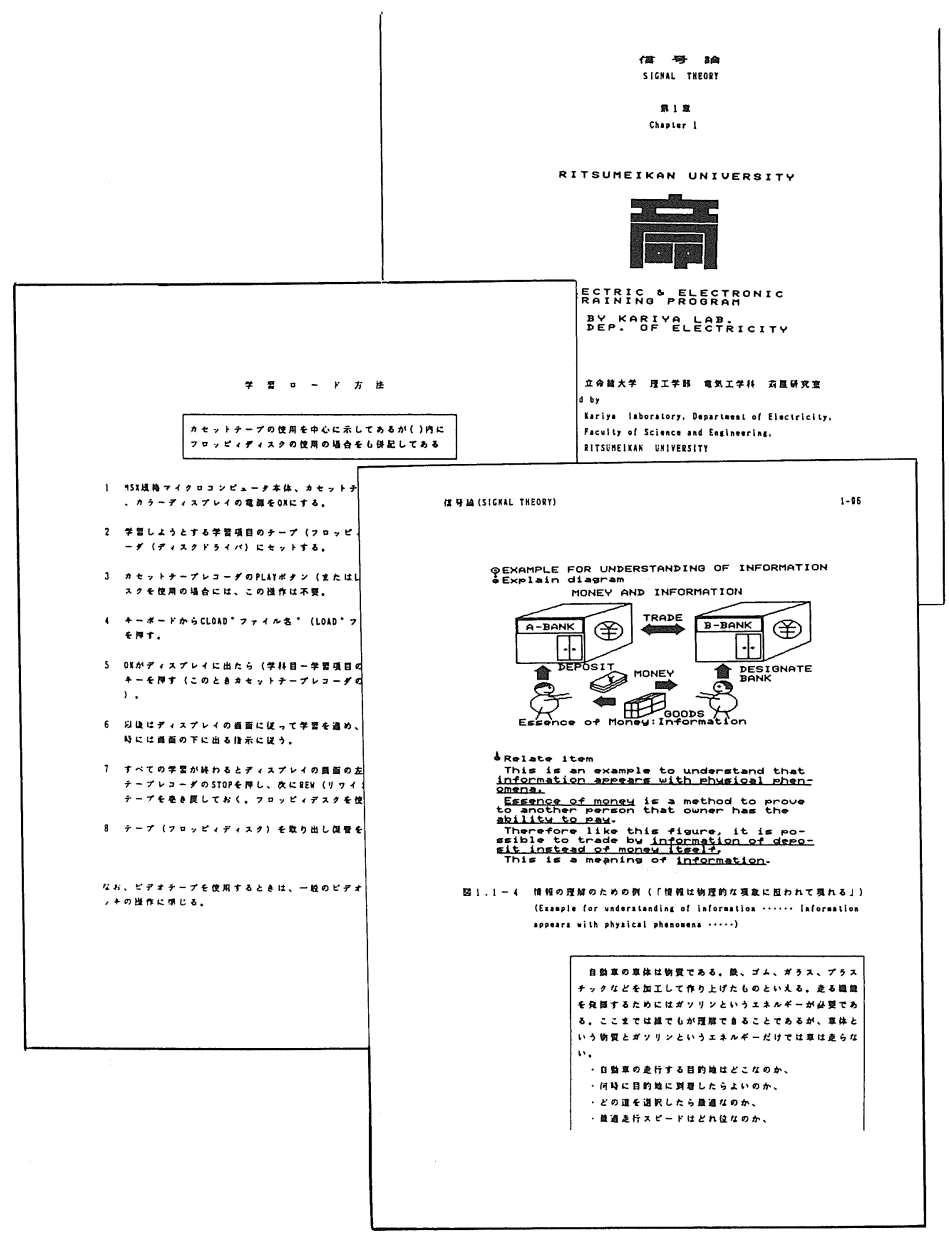

図 5 直観的・動的グラフィックスのハードコピーを使用した教科書原稿の作成例 